\title{
Luminescent biofunctional collagen mimetic nanofibers
}

\author{
Xiuxia Sun, ${ }^{\dagger}, \neq$ Manman He, ${ }^{\dagger}, \neq$ Lang Wang, ${ }^{\dagger}$ Liting Luo,\# Jie Wang,, Jianxi \\ Xiao $^{\dagger, * *}$
}

†State Key Laboratory of Applied Organic Chemistry, Key Laboratory of Nonferrous Metal Chemistry and Resources Utilization of Gansu Province, College of Chemistry and Chemical Engineering, Lanzhou University, Lanzhou 730000, P. R. China

\# Key laboratory of Magnetic Resonance in Biological Systems, State Key Laboratory of Magnetic Resonance and Atomic and Molecular Physics, Wuhan Institute of Physics and Mathematics, Chinese Academy of Sciences, Wuhan, 430071, China.

Submitted to

ACS Omega

\#Equal Contribution.

${ }^{*}$ Corresponding E-mail address: xiaojx@1zu.edu.cn 
Table S1. Design and thermal stability of lanthanide-triggered self-assembling collagen mimetic peptides.

\begin{tabular}{ccc}
\hline Peptide & Sequence & $\mathbf{T}_{\mathbf{m}}\left({ }^{\circ} \mathbf{C}\right)$ \\
\hline $\mathrm{CMP} 1$ & $\mathrm{DD}(\mathrm{GPP})_{5} \mathrm{GDP}(\mathrm{GPP})_{6} \mathrm{DD}$ & 37 \\
\hline $\mathrm{CMP} 2$ & $\mathrm{DD}(\mathrm{GPO})_{3} \mathrm{GDOGPOGFOGERGPOGDO}(\mathrm{GPO})_{3} \mathrm{DD}$ & 43 \\
\hline $\mathrm{CMP} 3$ & $\mathrm{EE}(\mathrm{GPO})_{3} \mathrm{GEOGPOGFOGERGPOGEO}(\mathrm{GPO})_{3} \mathrm{EE}$ & 48 \\
\hline
\end{tabular}
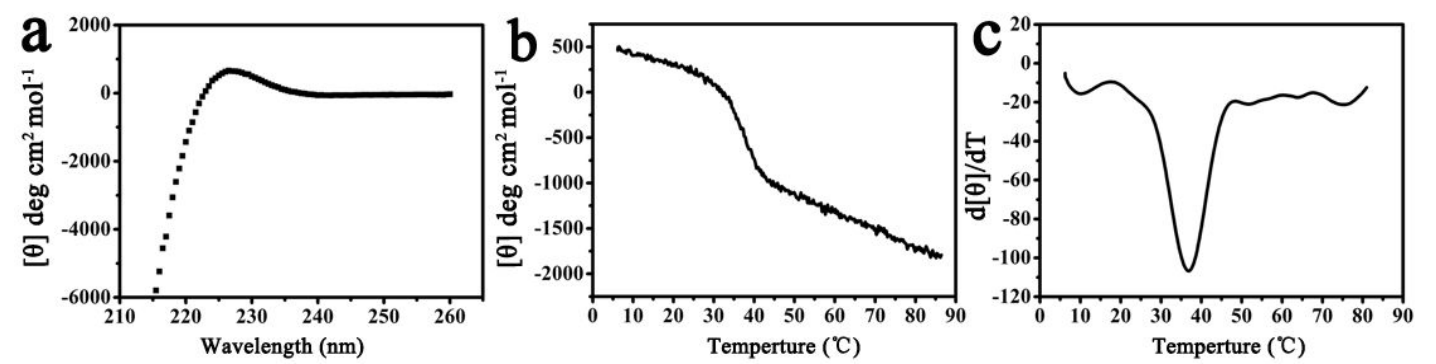

Figure S1. CD characterization of peptide CMP1. CD spectra (a), CD thermal unfolding (b), and the first derivative $(\mathrm{d}[\theta] / \mathrm{dT})$ of the $\mathrm{CD}$ unfolding curve (c) of peptide CMP1 at $\mathrm{pH} 7$ in $20 \mathrm{mM}$ Tris-HCl buffer.
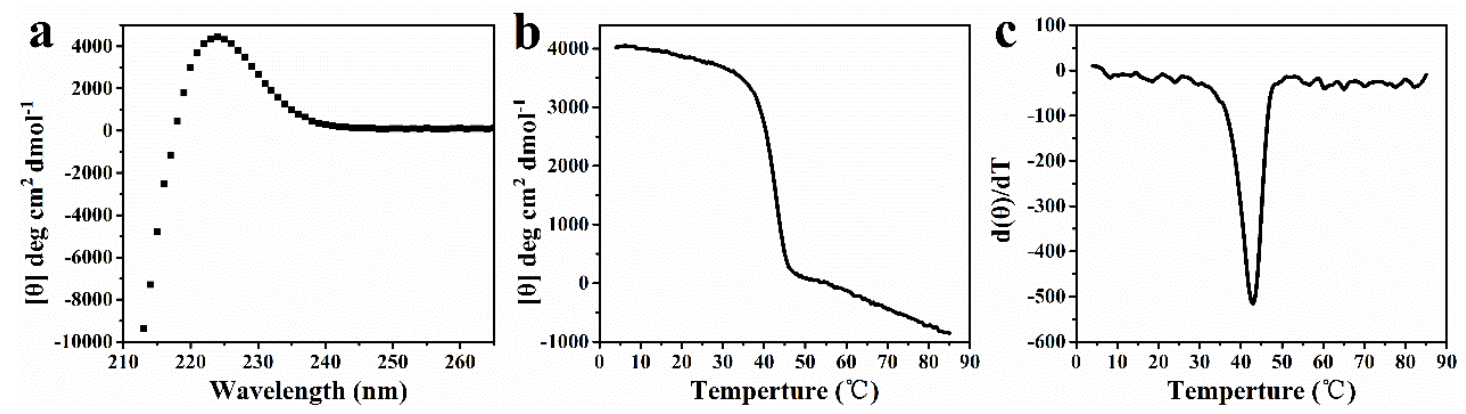

Figure S2. CD characterization of peptide CMP2. CD spectra (a), CD thermal unfolding (b), and the first derivative $(\mathrm{d}[\theta] / \mathrm{dT})$ of the CD unfolding curve (c) of peptide CMP2 at $\mathrm{pH} 7$ in $20 \mathrm{mM}$ PB buffer.
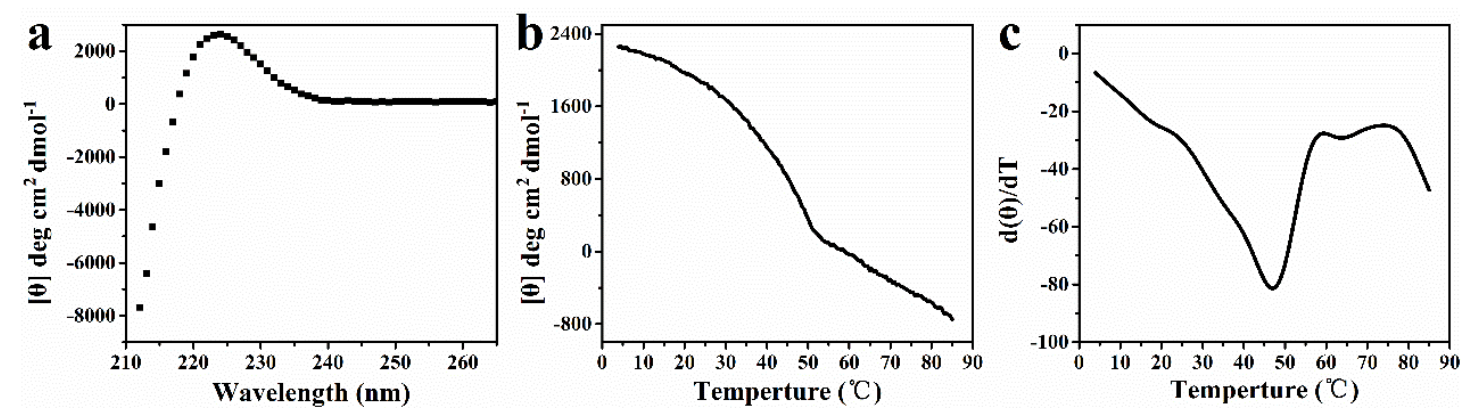

Figure S3. CD characterization of peptide CMP3. CD spectra (a), CD thermal unfolding (b), and the first derivative $(\mathrm{d}[\theta] / \mathrm{dT})$ of the CD unfolding curve (c) of peptide CMP3 at pH 7 in $20 \mathrm{mM}$ PB buffer. 


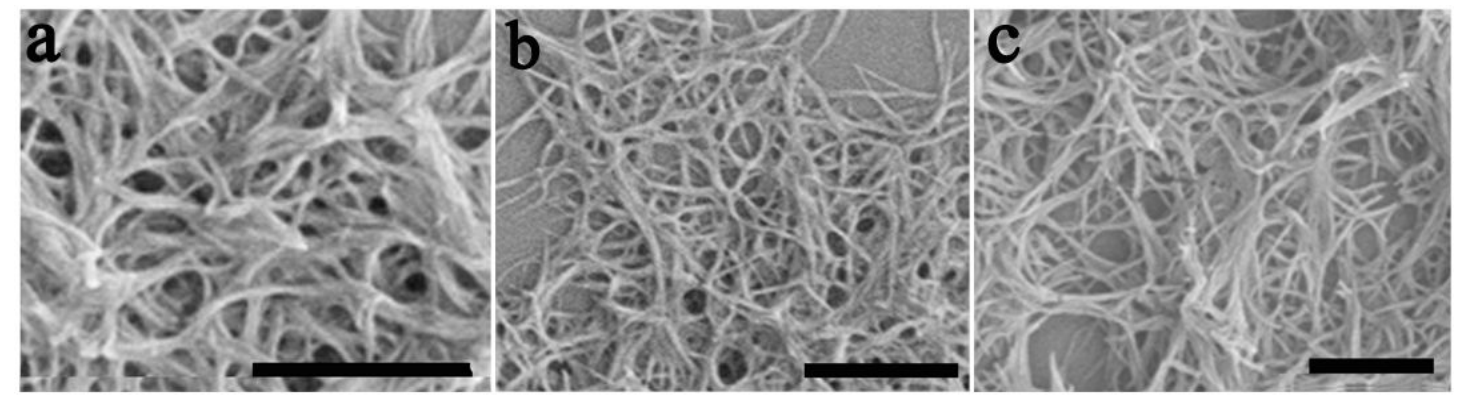

Figure S4. SEM images of peptide CMP1 with $\mathrm{La}^{3+}$ at different molar ratios $\left(\mathrm{La}^{3+}: \mathrm{CMP} 1\right): 1: 1$ (a), 2:1 (b), and 4:1 (c). The peptide-La ${ }^{3+}$ aggregates were collected after incubation at $25^{\circ} \mathrm{C}$ for 48 hrs. Scale $\mathrm{bar}=1 \mu \mathrm{m}$.
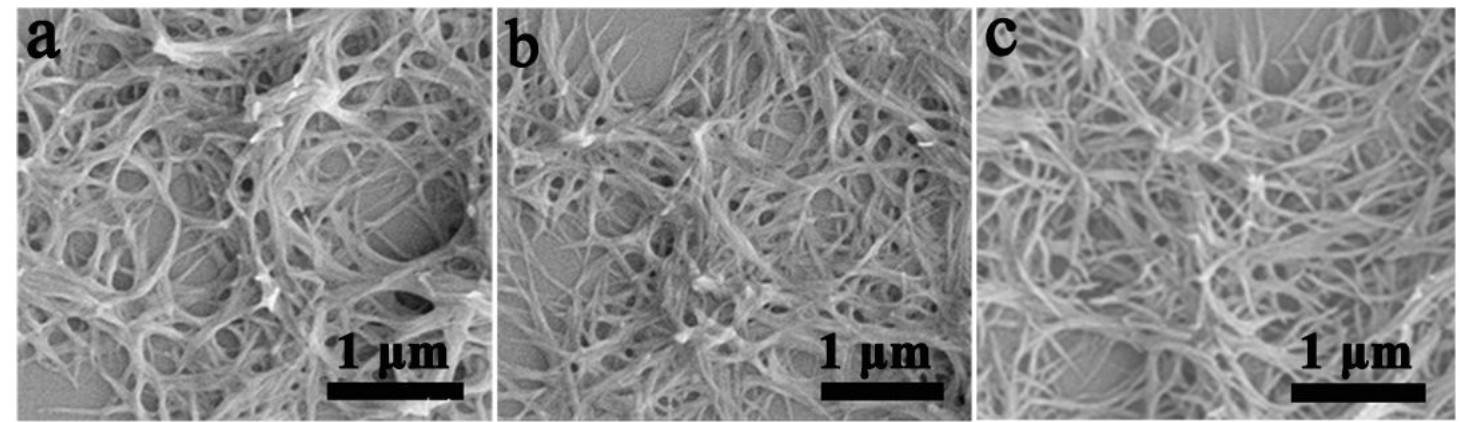

Figure S5. SEM images of peptide CMP1 with $\mathrm{La}^{3+}$ for different incubation time: $12 \mathrm{hrs}(\mathrm{a}), 24 \mathrm{hrs}$ (b) and $48 \mathrm{hrs}$ (c). The molar ratio of $\mathrm{La}^{3+}: \mathrm{CMP} 1$ was $2: 1$. Scale bar $=1 \mu \mathrm{m}$.
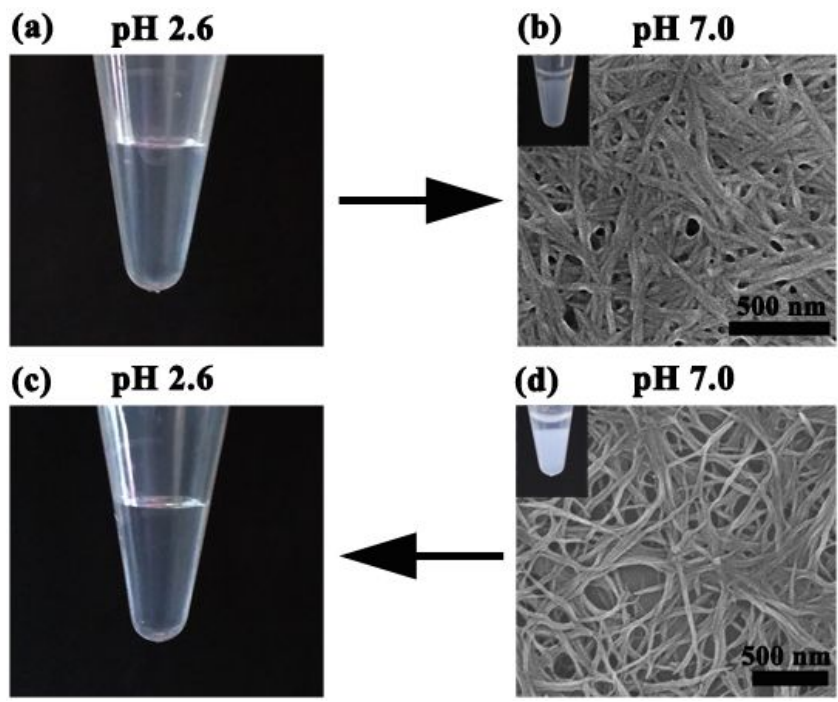

Figure S6. The reversibility of the $\mathrm{pH}$-mediated peptide CMP1-La ${ }^{3+}$ assembly. Photographs show the visual changes of the peptide CMP1-La ${ }^{3+}$ solution adjusted from $\mathrm{pH} 2.6$ (a) to $\mathrm{pH} 7.0$ (b) as well as the reverse process from $\mathrm{pH} 7.0$ (d) to $\mathrm{pH} 2.6$ (c). SEM images of the peptide CMP1-La ${ }^{3+}$ aggregates generated at $\mathrm{pH} 7.0$ during the processes were obtained $(\mathrm{b}, \mathrm{d})$. The molar ratio of CMP1: $\mathrm{La}^{3+}$ is 1:2. 


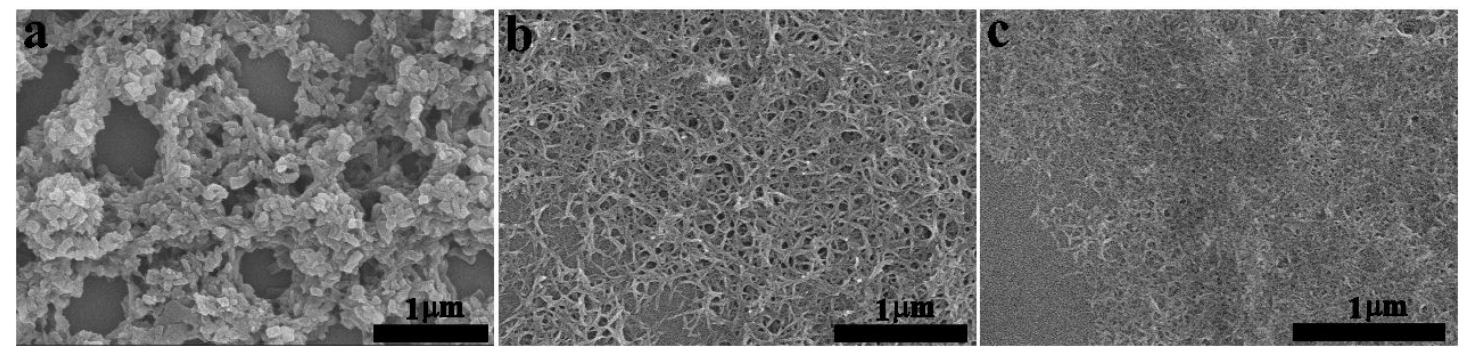

Figure S7. pH dependence of the peptide CMP2-La ${ }^{3+}$ assembly. SEM images of the peptide CMP2-La ${ }^{3+}$ assembled materials prepared at different pHs: pH 4.0 (a), pH 6.0 (b), and pH 7.0 (c). Scale bar $=1.0 \mu \mathrm{m}$.

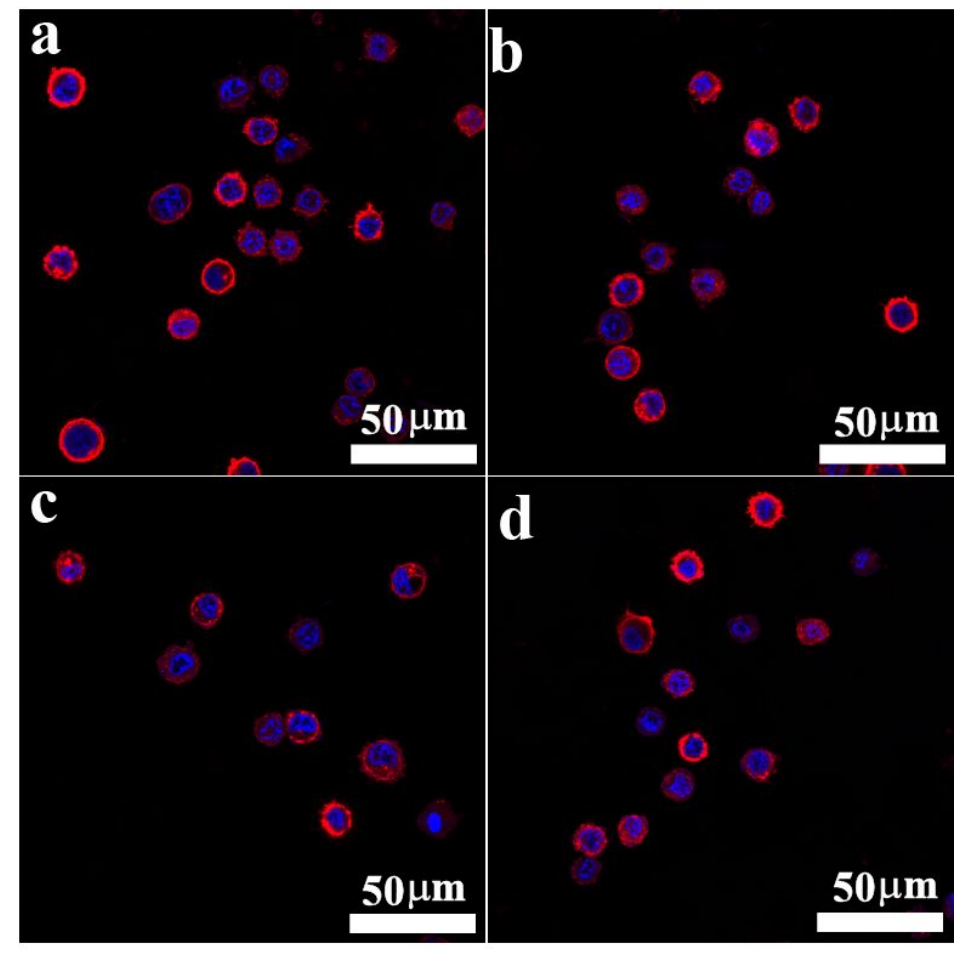

Figure S8. Cell adhesion and spreading of HeLa cells as a function of the CMP1-La ${ }^{3+}$ nanomaterials produced at different pH conditions: $\mathrm{pH} 7.0$ (a), pH 6.0 (b), pH 5.0 (c) and pH 4.0 (d). Cells were fixed and stained for actin stress fibers (red) and nuclei (blue).

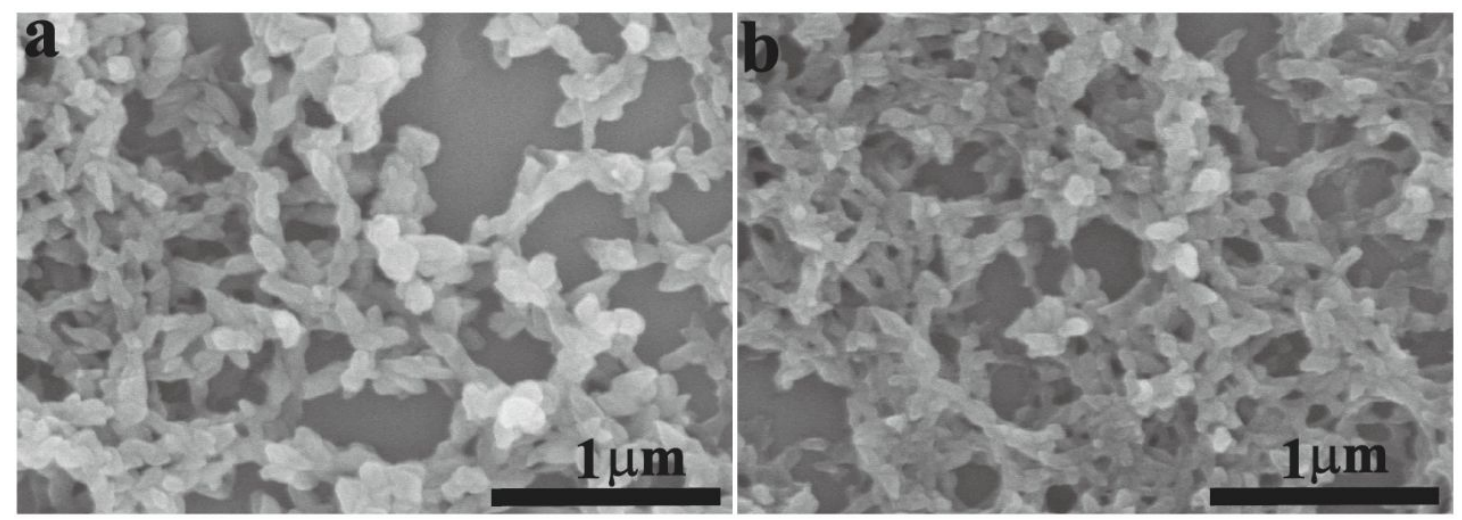

Figure S9. $\mathrm{pH}$ dependence of the peptide CMP3-La ${ }^{3+}$ assembly. SEM images of the peptide CMP3-La ${ }^{3+}$ assembled materials prepared at different pHs: pH 5.0 (a) and pH 6.0 (b). Scale bar $=1.0 \mu \mathrm{m}$. 


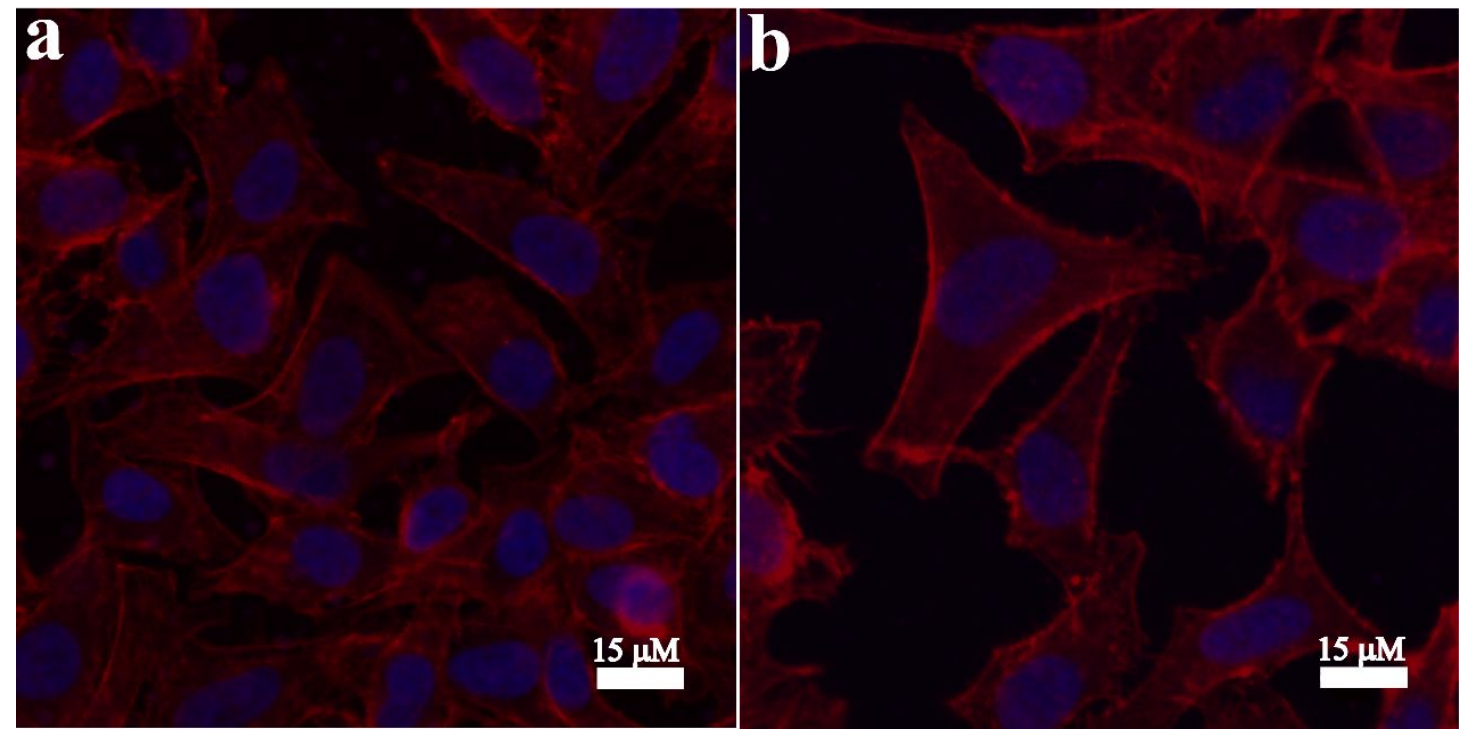

Figure S10. Cell adhesion and spreading of HeLa cells as a function of the CMP3-La ${ }^{3+}$ nanomaterials produced at different $\mathrm{pH}$ conditions: $\mathrm{pH} 5.0$ (a) and $\mathrm{pH} 6.0$ (b). Cells were fixed and stained for actin stress fibers (red) and nuclei (blue). 